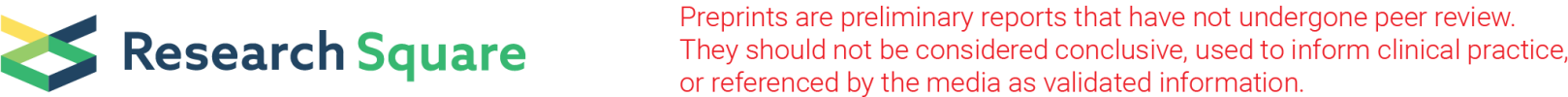

\section{Atractylenolide-I suppresses tumorigenesis of breast cancer by inhibiting toll-like receptor 4 (TLR4)-mediated NF-KB signaling pathway}

\section{Fangyi Long}

Sichuan Provincial Maternity and Child Health Care Hospital

Hong Lin

Sichuan Cancer Hospital and Institute

\section{Xiqian Zhang}

Chengdu Third People's Hospital

Jianhui Zhang

Sichuan Cancer Hospital and Institute

Hongtao Xiao

Sichuan Cancer Hospital and Institute

Ting Wang ( $\sim$ 309675263@qq.com )

Sichuan Cancer Hospital and Research Institute

\section{Research}

Keywords: Atractylenolide-I, Tumorigenesis, Breast cancer, TLR4-mediated NF-KB signaling pathway

Posted Date: August 25th, 2020

DOl: https://doi.org/10.21203/rs.3.rs-64359/v1

License: () (1) This work is licensed under a Creative Commons Attribution 4.0 International License. Read Full License 


\section{Abstract}

Background: Toll-like receptor 4 (TLR4) is an essential sensor related to tumorigenesis, and overexpression of TLR4 in human tumors often correlates with poor prognosis. Atractylenolide I (AT-I) is a major bioactive component from Rhizoma Atractylodes Macrocephalae. Emerging evidence suggests that AT-I exerts anti-tumor effects on various cancers such as colorectal cancer, bladder cancer and melanoma. Nevertheless, the effects of AT-I on mammary tumorigenesis remain unclear.

Methods: In order to ascertain the correlation of TLR4/NF-KB pathway with breast cancer, the expression of TLR4 and NF-KB in normal breast tissues and cancer tissues with different TNM-stages was detected by human tissue microarray (TMA) and immunohistochemistry technology. The effects of AT-I on tumorigenesis were investigated by cell viability, colony formation, apoptosis, migration and invasion assays in two breast cancer cells (MCF-7 and MDA-MB-231), and N-Nitroso-N-methylurea (NMU) induced rat breast cancer models were developed to evaluate the anti-tumor effects of AT-I in vivo. The possible underlying mechanisms were further explored by western blot and ELISA assays after a series of LPS treatment and TLR4 knockdown experiments.

ResultsవWe found that TLR4 and NF-KB were significantly up-regulated in breast cancer tissues, and was correlated with advanced TNM-stages. AT-I could inhibit TLR4 mediated NF-KB signaling pathway and decrease NF-KB-regulated cytokines in breast cancer cells, thus inhibiting cell proliferation, migration and invasion, and inducing apoptosis of breast cancer cells. Furthermore, AT-I could inhibit NMU-induced rat mammary tumor progression through TLR4/NF-KB pathway.

Conclusions: Our findings demonstrated that TLR4 and NF-KB were over expressed in breast cancer, and AT-I could suppress tumorigenesis of breast cancer via inhibiting TLR4-mediated NF-KB signaling pathway.

\section{Background}

Breast cancer, a malignancy stemming from mammary epithelial tissues, stood as the most common cancer in women, and the second contributory factor of cancer related women death all over the world [1]. Despite recent improvements in surgical excision, chemotherapy and radiotherapy of breast cancer, patients are often afflicted by various complications such as axillary vein thrombosis, neuropathy and cardiovascular diseases [2]. Furthermore, the current available treatments with two selective ER modulators (SERMs), tamoxifen and raloxifene, approved by the FDA for breast cancer chemoprevention, remain unsatisfactory due to the drug resistance and side-effects such as hepatic injury [3]. Therefore, it is crucial to identify the underlying mechanisms involved in tumorigenesis of breast cancer, and facilitate the finding of more effective treatment strategies against breast cancer.

Toll-liked receptors (TLRs), mainly expressing in human immune related cells, plays a crucial role in the first line of host defense by recognizing pathogen-associated molecular patterns (PAMPs) [4, 5]. TLRs could also adjust inflammatory microenvironment, which is vital to tumorigenesis, and multiple effects 
had been identified by activating TLRs. Various TLRs agonists are currently under investigation for their ability in anticancer immunotherapy [6-8]. While several other studies provided evidence that TLRs ligands such as lipopolysaccharide (LPS) was associated with epithelial-to-mesenchymal transition (EMT) and accelerated metastatic tumor growth through TLR4 $[9,10]$. In addition, the expression of TLR4 was the highest among other TLRs in human breast cancer, and TLR4 activation could subsequently activate nuclear factor-KB (NF-KB) and produce pro-inflammatory cytokines, ultimately stimulating inflammation $[11,12]$.

Last few years, naturally existed chemicals have attracted widespread attentions for being identified as new preventive agents against cancer, with high anti-inflammatory efficacy and low toxicity. Rhizoma Atractylodis Macrocephalae, one of the traditional Chinese crude materials, had significant gastrointestinal tract protective, neuroprotective and immunomodulatory activities [13], and numerous lines of evidence showed that it also exerted anti-tumor, anti-inflammatory and antioxidant effects [13, 14]. Atractylenolide I (AT-I), the major bioactive component from Rhizoma Atractylodes Macrocephalae, also had multiple therapeutic activities including anti-inflammatory $[15,16]$ and anti-tumor effects [1719]. Specifically, AT-I could ameliorate LPS-induced lung damages in mouse model [15], and suppressed LPS-induced NO release and diminished pro-inflammatory cytokines levels in BV-2 cells [16]. AT-I had the anti-tumor effects against many cancers, such as colorectal cancer [17], non-small cell lung cancer [18] and melanoma [19], and it also had a binding site similar to LPS and served as a novel TLR4antagonizing agent [20]. Moreover, a randomized pilot study of AT-I on gastric cancer cachexia patients showed that AT-I could inhibit pro-inflammatory cytokines and proteolysis-inducing factor (PIF) proteolysis, and then alleviating symptoms of gastric cancer cachexia patients [21]. However, the effects of AT-I on mammary tumorigenesis remain largely unknown.

In this study, we investigated the effects of AT-I on mammary tumorigenesis, and explored the possible mechanisms. We found that TLR4 and NF-KB were over expressed in human breast cancer tissues, and activation of TLR4/NF-KB pathway was correlated with advanced TNM-stages. We also found that AT-I could inhibit cell proliferation, migration, invasion and induce apoptosis. Further investigation revealed that AT-I could inhibit TLR4/NF-KB pathway, resulting in decreased proinflammatory factors expression, and these chemopreventive effects of AT-I were TLR4-dependent. Furthermore, in vivo studying demonstrated that AT-I suppressed tumorigenesis of breast cancer via inhibiting TLR4/NF-KB pathway. All these results suggested that AT-I could be a potential agent in suppressing tumorigenesis of breast cancer.

\section{Materials And Methods}

\section{Materials}

The human breast cancer cell lines (MCF-7 and MDA-MB-231) and mammary epithelial cell line (MCF 10A) were obtained from the American Type Culture Collection (Manassas, VA, USA). Atractylenolide-I (ATI) was purchased from Solarbio (Beijing, China). MTT (3-[4, 5-dimethylthiazol-2-yl]-2, 5-diphenyl 
tetrazolium bromide) was from Sigma-Aldrich (St. Louis, MO, USA). The primary antibodies used in this study, targeting TLR4, MyD88, p-NF-KB p65, NF-KB p65, p-ІкBa, ІкBa, p-IKKa/ $\beta$, IKKa, IKK $\beta$ and $\beta$-actin are listed in Table 1. Recombinant retroviral GFP vector harboring a short-hairpin RNA (shRNA) sequence targeting TLR4 (shTLR4) and its scramble vector (shNC) were purchased from OriGene (Rockville, MD, USA). Annexin V-APC/PI apoptosis detection kit was from Keygen (Nanjing, China). The human and rat ELISA kits for interleukin-6 (IL-6), interleukin-1 $\beta$ (IL-1 $\beta$ ) and tumor necrosis factor-alpha (TNF-a) were purchased from Dakewe (Shenzheng, China).

Table 1 Primary antibodies used in this study

\begin{tabular}{llll}
\hline \multicolumn{1}{c}{ Antibody } & \multicolumn{1}{c}{ Description } & Application & \multicolumn{1}{c}{ Source } \\
\hline TLR4 & Transmembrane receptor & WB, IHC & Santa Cruz \\
MyD88 & Myeloid differentiation protein & WB & Santa Cruz \\
p-NF-к B p65 & Activated transcription factor & WB & Santa Cruz \\
NF-к B p65 & Transcription factor & WB, IHC & Santa Cruz \\
p-Ik B $\alpha$ & Activated inhibitory protein of NF-кB & WB & Cell signaling technology \\
IкB $\alpha$ & Inhibitory protein of NF-кB & WB & Cell signaling technology \\
p-IKK $\alpha / \beta$ & Activated IkB kinase & WB & Cell signaling technology \\
IKK $\alpha$ & IkB kinase & WB & Cell signaling technology \\
IKK $\beta$ & Iк B kinase & WB & Cell signaling technology \\
$\beta$-actin & Cytoskeletal protein & WB & Boster \\
\hline
\end{tabular}

WB: Western blot.

IHC: Immunohistochemistry.

\section{Tissue microarrays and immunohistochemistry}

Commercial tissue microarray (Alenabio Biotechnology, Xi'an, China), composed of 8 samples of normal or cancer-adjacent breast tissues and 40 samples of breast cancer tissues, was used to evaluate the expression of TLR4 and NF-KB. The tumor tissues included 9 cases of Stage I disease, 25 cases of Stage II disease and 6 cases of Stage III disease. All experiment protocols were approved by the Ethics Committee of Sichuan Provincial Maternity and Child Health Care Hospital (Chengdu, China).

Immunohistochemistry was performed on the human breast tissue microarray. The slides were deparaffinized and rehydrated in graded ethanol solutions. After wet autoclave pretreatment for antigen retrieval and suppressing endogenous peroxidase activity, the slides were blocked with $5 \%$ bovine serum albumin (BSA). The anti-TLR4 monoclonal antibody (1:100) and NF-KB p65 (1:100) were applied for $1 \mathrm{~h}$ at $37^{\circ} \mathrm{C}$, and SABC Staining System kit (Boster, Wuhan, China) containing secondary antibody was used. Immunoreactivity was visualized using 3,3'-diaminobenzidine (Boster, Wuhan, China).

Immunohistochemistry evaluation was performed independently by two researchers. A semi-quantitative HistoScore (H-score, ranged from 0 to 300 ) for each specimen was calculated by multiplying the percentage of positive areas $(0-100 \%)$ by intensity $(0=$ nil; $1=$ weak; $2=$ moderate; $3=$ strong $)$ [22].

\section{Cell culture and transfection}


MCF-7 and MDA-MB-231 cells were cultured in Dulbecco's Modified Eagle's Medium (Gibco, Carsbad, CA, USA) supplemented with $10 \%$ fetal bovine serum (Gibco) and $100 \mathrm{U} / \mathrm{ml}$ of penicillin and $100 \mu \mathrm{g} / \mathrm{ml}$ streptomycin, and at $37^{\circ} \mathrm{C}$ in a $5 \% \mathrm{CO}_{2}$ atmosphere. MCF 10A cells were cultured in DMEM/F12 (Gibco) supplemented with $5 \%$ heat-inactivated horse serum (Gibco), $100 \mathrm{ng} / \mathrm{ml}$ Cholera toxin, $10 \mu \mathrm{g} / \mathrm{ml}$ insulin, $20 \mathrm{ng} / \mathrm{ml}$ recombinant EGF, $0.5 \mu \mathrm{g} / \mathrm{ml}$ hydrocortisone, $100 \mathrm{U} / \mathrm{ml}$ of penicillin and $100 \mu \mathrm{g} / \mathrm{ml}$ streptomycin at $37^{\circ} \mathrm{C}$ in a $5 \% \mathrm{CO}_{2}$ atmosphere.

To confirm that TLR4 could mediate the tumorigenesis inhibitory effects of AT-I, the shTLR4 plasmid and lipofectamine ${ }^{\circledR} 3000$ (Invitrogen, Carsbad, CA, USA) were used to conduct the transfection. The knockdown studies were performed at $48 \mathrm{~h}$ after transfection.

\section{Cell viability assay}

MCF-7 and MDA-MB-231 cells viability were measured by MTT assay. The cells were seeded into 96-well plates $\left(1 \times 10^{4}\right.$ cells/well) and incubated for $24 \mathrm{~h}$. After treatment with AT-I $(0,25,50,100$ and $200 \mu \mathrm{M})$ for 24,48 and $72 \mathrm{~h}$, the cells in each well were incubated with $10 \mu \mathrm{MTT}(5 \mathrm{mg} / \mathrm{ml})$ for $4 \mathrm{~h}$ at $37^{\circ} \mathrm{C}$, and then MTT was dissolve with $150 \mu$ DMSO. The absorbance was measured using a Multiskan MK3 Reader (Thermo Fisher Scientific, Waltham, MA, USA) at $570 \mathrm{~nm}$ wavelength.

\section{Annexin V-APC/PI staining and apoptosis assay}

Annexin V-APC and propidium iodide (PI) staining was used to detect the effects of AT-I on apoptosis of MCF-7 and MDA-MB-231 cells. Briefly, the cells were seeded in 6-well plates $\left(3 \times 10^{5}\right.$ cells/well) and treated with AT-I $(0,25,50$ and $100 \mu \mathrm{M})$ or vehicle $(0.1 \%$ DMSO) for $48 \mathrm{~h}$, respectively. The cells were then trypsinized, washed twice with ice-cold PBS, re-suspended and incubated with binding buffer that containing Annexin V-APC and PI labeling reagents at room temperature for $15 \mathrm{~min}$ in the dark. Early apoptotic cells (Annexin V-APC-positive and PI-negative $\left[\mathrm{Ann}^{+} / \mathrm{PI}\right]$ ) and late-stage apoptotic [dual Annexin V-APC-positive and PI-positive [ $\left.\mathrm{Ann}^{+} / \mathrm{PI}^{+}\right]$] were examined by flow cytometer (Beckman Coulter, Fullerton, CA, USA).

\section{Cell migration assay}

Wound healing assay was adopted to detect the migration abilities of MCF-7 and MDA-MB-231 cells. Briefly, the cells were seeded and grew to $80 \%$ confluence in 24 -well plates, and we creat a wound by scratching cells with a sterile $200 \mu \mathrm{L}$ pipette tip. Then, cells were continued to incubate in the medium in the absence or presence of 25,50 and $100 \mu \mathrm{M}$ AT-I for $48 \mathrm{~h}$. The cells grew into wound surface were considered as migrated cells, and photographed by microscope (Nikon, Japan). The wound width difference of $0 \mathrm{~h}$ and $48 \mathrm{~h}$ was used to calculated the rate of wound healing.

\section{Cell invasion assay}


Transwell chambers (Millipore, Billerica, MA, USA) with $8.0 \mu \mathrm{m}$ pore membranes were coated with matrigel (BD, Franklin Lakes, NJ, USA) and used for invasion analysis. In brief, cells were treated with 0 , 25, 50 and $100 \mu \mathrm{M}$ AT-I. After for $48 \mathrm{~h}$, cells were collected by trypsin and resuspended in $200 \mu \mathrm{L}$ serumfree medium, and then seeded on the upper chamber ( $5 \times 10^{4}$ cells/well). $600 \mu \mathrm{L}$ complete medium was added to the lower chamber as a chemoattractant. After $24 \mathrm{~h}$ incubation, the cells remaining at the upper surface of the membrane were removed, and the cells on the lower surface, regarded as invasive cells. After fixing with $4 \%$ paraformaldehyde, the cells were stained with $0.5 \%$ crystal violet solution. The invasive cells were photographed and counted under microscope.

\section{Colony formation assay}

MCF-7 and MDA-MB-231 cells were seeded in 6-well plates (500 cells/well), and cultivated in medium containing AT-I $(0,25,50$, and $100 \mu \mathrm{M})$ for $48 \mathrm{~h}$. Cells were maintained in the well for 14 days to form colony, and the colonies were fixed and stained with $0.5 \%$ crystal violet solution ( $30 \%$ methanol) for 30 minutes at room temperature. The numbers of colonies with $\geq 50$ cells were counted under microscope.

\section{Animal and experimental procedures}

Twenty-four female Sprague-Dawley (SD) rats (Dashuo, Chengdu, China) were randomly distributed into four groups. After pretreatment with vehicle or AT-I ( $100 \mathrm{mg} / \mathrm{kg}$ and $200 \mathrm{mg} / \mathrm{kg})$ for 3 days, a single dose of NMU $(75 \mathrm{mg} / \mathrm{kg})$ was intraperitoneal injected to the rats at 21 days of age, and continued to treat with vehicle or AT-I daily for 9 weeks. Then they were sacrificed, and cancer samples were collected and kept at $-80^{\circ} \mathrm{C}$ for western blot and ELISA analysis.

\section{Protein lysate preparation and western blot assay}

The total protein was isolated from cell lysates using RIPA buffer (Beyotime, Shanghai, China) according to the manufacturer's instructions. Equal amounts of protein were separated by gel electrophoresis, and then transferred to a polyvinylidene fluoride membrane (Bio-Rad, Hercules, CA, USA). After blocked with $5 \%$ BSA, the membrane was incubated with primary antibody (Table 1 ) overnight at $4{ }^{\circ} \mathrm{C}$, washed three times, and subsequently incubated with horseradish peroxidase-conjugated secondary antibody (ZSGB, Beijing, China) for $2 \mathrm{~h}$ at $25^{\circ} \mathrm{C}$. The density analysis of each band was conducted using Image Lab 5.0 software (Bio-Rad).

\section{ELISA assay}

For measurements of TNF- $a, \mathrm{IL}-6$ and IL-1 $\beta$, the supernatants of cell culture medium and rat tissue lysis were collected to performe ELISA analysis according to the manufacturer's protocol.

\section{Statistical analysis}

The data was expressed as the mean \pm SEM and analyzed using one-way analysis of variance (ANOVA) followed by the Tukey test. The statistical analysis was performed using SPSS 16.0 software. Values of $p$ 
$<0.05$ were considered statistically significant.

\section{Results}

\section{TLR4 and NF-KB were up-regulated in human breast cancer tissues and correlated with TNM-stages}

To study the role of TLR4/NF-KB pathway in breast cancer, we assessed the expression of TLR4 and NF$\mathrm{KB}$ in normal breast tissues and different TNM-stages breast cancer tissues using tissue microarray and immunohistochemistry technology. The results showed that TLR4 and NF-KB levels in breast cancer tissues were significantly higher than that in normal breast tissues (Fig. 1a-b). Furthermore, we found that the expression of TLR4 and NF-KB in high TNM stages was significantly higher than that in low TNMstages of breast cancer (Fig. 1a-b). In addition, we detected the expression of TLR4 and NF-KB in MCF-7, MDA-MB-231 and MCF 10A cells by western blot assay. As shown in Fig. 1c-d, TLR4 and NF-KB levels in breast cancer cells were significantly higher than that in mammary epithelial cells. These results indicated that the expression of TLR4 and NF-KB were up-regulated in human breast cancer tissues and cells, and their high expression was correlated with advanced TNM-stages in breast cancer patients.

\section{AT-I inhibited cell growth and induced apoptosis}

Cell viability was determined by MTT assay after AT-I treatment, and the results (Fig. 2a) demonstrated that AT-I cytotoxicity was dose- and time-dependent in both MCF-7 and MDA-MB-231 cells, with the IC50 values $(251.25 \pm 27.40) \mu \mathrm{M},(212.44 \pm 18.76) \mu \mathrm{M}$ and $(172.49 \pm 18.32) \mu \mathrm{M}$ for $24 \mathrm{~h}, 48 \mathrm{~h}$ and $72 \mathrm{~h}$ in MCF-7 cells, respectively; and $(164.13 \pm 17.90) \mu \mathrm{M}$, (139.21 \pm 17.67$) \mu \mathrm{M}$ and $(105.68 \pm 10.58 \mu \mathrm{M})$ in MDA-MB-231 cells, respectively. Furthermore, there was a significant inhibition of colony formation after AT-I treatment (Fig. 2b), suggesting that AT-I could inhibit cell proliferation and tumorigenic ability of MCF7 and MDA-MB-231 cells.

To further investigate the anti-tumor activities of AT-I, we tested effects of AT-I on cell apoptosis. The MCF-7 and MDA-MB-231 cells were treated with AT-I at different concentrations for $48 \mathrm{~h}$. The percentage of live cells (Q1-LL), early apoptotic (Q1-LR), late apoptotic (Q1-UR), and necrotic (Q1-UL) of MCF-7 and MDA-MB-231 cells were determined by flow cytometry. The results indicated that AT-I could induce apoptosis in a dose-dependent manner in both MCF-7 and MDA-MB-231 cells (Fig. 2c-d).

\section{AT-I inhibited breast cancer cell migration and invasion}

We explored the effects of AT-I on cell migration and invasion, and the wound healing assay suggested that the migration of MCF-7 and MDA-MB-231 cells was significantly inhibited by $50 \mu \mathrm{M}$ or $100 \mu \mathrm{M}$ AT-I treatment for $48 \mathrm{~h}$ (Fig. 3a). The transwell invasion assay showed that the number of cells invading the lower chamber was markedly decreased after $50 \mu \mathrm{M}$ or $100 \mu \mathrm{M}$ AT-I treatment, compared with the control cells (Fig. 3b). In addition, as dose increased, AT-I has stronger inhibitory effects on the migration and invasion of MCF-7 and MDA-MB-231 cells. Taken together, these results strongly demonstrated that AT-I treatment resulted in effective inhibition of migration and invasion in breast cancer cells. 


\section{AT-I inhibited TLR4/NF-KB pathway in breast cancer cells}

AT-I was reported to be a novel TLR4-antagonizing agent [20], and we used western blot to detect the effects of AT-I on TLR4/NF-KB pathway in MCF-7 and MDA-MB-231 cells. After AT-I treatment, the expression of TLR4, MyD88, $p-N F-K B$ p65, $p$-IKBa and $p-I K K a / \beta$ was significantly down-regulated in a dose-dependent manner in both cells(Fig. 4a-b). Furthermore, we used LPS (TLR4 agonist) induced cell inflammation to measure the levels of NF-KB related pro-inflammatory cytokines by ELISA assays. The results showed that the levels of the NF-KB-regulated cytokines (i.e., TNF-a, IL-6 and IL-1 $\beta$ ) were all decreased after AT-I treatment. These data suggested that AT-I could inhibit TLR4/NF-KB pathway, and down-regulate the downstream pro-inflammatory cytokines in breast cancer cells.

\section{The tumorigenesis inhibitory effects of AT-I is mediated by TLR4}

To confirm that TLR4 was essential in the tumorigenesis inhibitory effects of AT-I, the shTLR4 plasmid was adopted to transfect MCF-7 and MDA-MB-231 cells, and then western blot and ELISA assays were used to evaluate the changes of related protein levels after AT-I treatment. We found that the expression of TLR4, MyD88, p-NF-KB p65, p-IKBa and p-IKKa/ $\beta$ were significantly down-regulated after AT-I or shTLR4 treatment in LPS-induced MCF-7 and MDA-MB-231 cells. However, no inhibitory effects of AT-I on these protein levels were observed after shTLR4 transfection in LPS induced cells (Fig. 5a-b). To clearly demonstrate the mechanisms, the levels of secreted pro-inflammatory cytokines TNF-a, IL- 6 and IL-1 $\beta$ were determined by ELISA, and the results were consistent with western blot assays (Fig. 5c-d).

To further examine the role of TLR4 in the migration and invasion of breast cancer cells after AT-I treatment, the LPS induced MCF-7 and MDA-MB-231 cells were used for wound healing and transwell invasion assays. The results indicated that LPS could induce the migration and invasion activities of both MCF-7 and MDA-MB-231 cells, and treatment with AT-I or shTLR4 could decrease cell migration and invasion. However, in TLR4 knockdown cells, no inhibitory effects of AT-I on cell migration and invasion were observed, which indicated that TLR4 is essential for AT-I's inhibitory effects on cell migration and invasion (Fig. 6a-d).

\section{AT-I inhibited NMU-induced mammary tumor progression in rats}

The previous studies indicated that AT-I exerted tumorigenesis inhibition in vitro, and we next investigated these effects in vivo. We employed the NMU-induced rat breast cancer model, which is commonly accepted for candidate chemopreventive agents evaluation $[23,24]$. We firstly found that NMU treatment could significantly decrease the body weights of rats, while AT-I could revert these effects (Fig. 7a). In addition, the first palpable mammary tumors in the NMU-treated group appeared after 5 weeks of NMU treatment, but it did not appear until 6 and 7 weeks in $100 \mathrm{mg} / \mathrm{kg}$ and $200 \mathrm{mg} / \mathrm{kg}$ AT-I group, and all rats had tumors at 9 weeks (Fig. 7b). Averagely there were 3.67, 1.83 and 1.33 tumors monitored in the NMU, $100 \mathrm{mg} / \mathrm{kg}$ and $200 \mathrm{mg} / \mathrm{kg}$ AT-I treatment groups, respectively (Fig. 7c). Moreover, the mean tumor volume was significantly decreased in the $100 \mathrm{mg} / \mathrm{kg}$ and $200 \mathrm{mg} / \mathrm{kg}$ AT-I treatment group (Fig. 7d). These results indicated that AT-I treatment could inhibit the mammary tumorigenesis in rats. 
To further elucidate the underlying mechanisms of these effects, we detected the influence of AT-I on the TLR4/NF-KB pathway and its downstream proinflammatory factors in the NMU-induced mammary carcinogenesis. As shown in Fig. 6e-i, NMU treatment alone could induce TLR4, MyD88 and p-NF-KB p65 expression, and then increase its downstream proinflammatory factors TNF- $a$, IL- 6 and IL-1 $\beta$ levels. However, AT-I treatment could reduce the activation of TLR4/NF-KB pathway induced by NMU, and then decrease the TNF- $a$, IL- 6 and IL-1 $\beta$ level. Our findings suggested that AT-I could inhibit NMU-induced mammary tumor progression in rats through inhibiting TLR4/NF-KB pathway.

\section{Discussion}

It is well established that tumorigenesis is a multi-step process caused by various factors, such as environmental carcinogens, inflammatory mediators, and tumor promoters. Multiple effects had been identified of TLR4 in tumor progression [11, 25-28]. In breast cancer cells and primary breast cancer tissues from patients, TLR4 expression was found to be up-regulated both at mRNA and protein levels, and significantly correlated with the high incidence of lymph node metastasis [11,26]. Moreover, as TLRs ligands, LPS was reported to increase breast cancer metastasis in vitro and in vivo [27], and acquiring of high metastatic potential upon the TLR4-elicited activation of NF-KB in breast cancer cells was associated with integrin av $\beta 3$, TPM1 and maspin [28]. However, Connelly et al. suggested that inhibition of NF-KB might lead to the increased tumor latency and decreased tumor burden and numbers of lung metastases during breast cancer development in mice [29]. All these studies suggested that TLR4/NF-KB pathway played a critical role in the mammary tumorigenesis, but the underlying mechanisms need to be further elucidated.

To study the important role of TLR4/NF-KB pathway in breast cancer, we assessed the expression of TLR4 and NF-KB among normal breast tissues and different TNM-stages breast cancer tissues using tissue microarray and immunohistochemistry technology. The results showed that TLR4 and NF-KB were over expressed in breast cancer, and correlated with the TNM-stages. Furthermore, these differentially expressed levels of TLR4 and NF-KB were also detected in breast cancer cells and mammary epithelial cells. These results indicated that TLR4 and NF-KB were up-regulated in breast cancer, and might function as tumor promoters in breast cancer.

AT-I is a novel TLR4-antagonizing agent [20], and it exerted anti-tumor effects on colorectal cancer, bladder cancer and melanoma [17-19], then we investigated whether it could suppress tumorigenesis in breast cancer via inhibiting TLR4/NF-KB pathway. Firstly, we found that AT-I could inhibit cell growth, proliferation, migration and invasion, and induce apoptosis in breast cancer cells. Then, we detected the effects of AT-I on the TLR4/NF-KB pathway in breast cancer cells. Previous studies have demonstrated that activation of TLR4 could lead to its dimerization, activation of the MyD88-dependent or -independent NF-KB signaling pathway, thus promoting tumor growth and invasion by regulating tumor immune and inflammatory response [30, 31]. Furthermore, TLR4 could activate the downstream IKB kinase (IKK) complex, and then phosphorylate $\mathrm{k} \mathrm{B}$, an NF-kB inhibitor that could prevent nuclear translocation of NFKB. Upon phosphorylation, IKB was degraded and released NF-KB, which then entered nucleus and 
mediated the expression of inflammatory cytokines [32, 33]. In the present study, we found that the expression of TLR4, MyD88, $\mathrm{p}-\mathrm{NF}-\mathrm{KB}$ p65, $\mathrm{p}-\mathrm{IkBa}$ and $\mathrm{p}-\mathrm{IKK} \mathrm{K} / \beta$ in breast cancer cells was significantly down-regulated after AT-I treatment. Furthermore, we used the LPS (TLR4 agonist) treatment as cell inflammation model, and measured the levels of secreted pro-inflammatory cytokines regulated by NF-KB. The results showed that the secretion of TNF- $a$, IL- 6 and IL-1 $\beta$ were all decreased after AT-I treatment, and we concluded that AT-I could suppress tumorigenesis in breast cancer via inhibiting TLR4/NF-KB pathway, and down-regulate downstream pro-inflammatory cytokines.

TLR4, in the frame of our investigation, played a pivotal function role in the tumorigenesis inhibition of AT-I by regulating NF-KB signaling pathway. We found that LPS could induce cell migration and invasion, and co-treatment with AT-I or shTLR4 could decrease the migration and invasion. However, in TLR4 knockdown cells, no inhibitory effects of AT-I on cell migration and invasion were observed, which indicated that TLR4 was essential in AT-I's effects. To further elucidate the underlying mechanisms, we examined the effects of TLR4 on the NF-KB signaling pathway and downstream pro-inflammatory cytokines, and we found that the expression of TLR4, MyD88, p-NF-KB p65, p-IKBa and p-IKKa/ $\beta$ and downstream pro-inflammatory cytokines TNF-a, IL-6 and IL-1 $\beta$ were significantly down-regulated after AT-I or shTLR4 treatment in LPS induced breast cancer cells. Similarly, in TLR4 knockdown cells, no inhibitory effects of AT-I on protein expression were observed, which indicated that AT-I's effects on these protein levels were TLR4-dependent. The results above demonstrated that AT-I suppressed tumorigenesis in breast cancer cells via inhibiting TLR4-mediated NF-KB signaling pathway.

We further confirmed these effects and mechanisms in vivo using NMU-induced rat breast cancer model [23], which shared a lot similarities with human mammary carcinomas including histopathology [34, 35]. Previously, we had used this model to explore the inhibitory effects of AT-II on breast cancer through regulating Nrf2/ARE pathway [24]. In the present study, we found that AT-I could inhibit the mammary tumorigenesis in rats, and the underlying mechanisms were further elucidated by detecting the effects of AT-I on TLR4/NF-KB pathway, and its downstream proinflammatory factors in breast cancer rats. The results indicated that TLR4, MyD88 and p-NF-KB p65 were up-regulated in NMU-induced breast cancer, along with its downstream pro-inflammatory factors. While AT-I treatment could down-regulate TLR4/NFKB pathway, and then decrease the TNF- $a$, IL- 6 and IL- $1 \beta$ levels in NMU-induce rats. Our findings suggested that AT-I could inhibit NMU-induced mammary tumor progression in rats by inhibiting of TLR4/NF-KB pathway.

\section{Conclusions}

This study demonstrated that TLR4 and NF-KB were over expressed in breast cancer, and AT-I could suppress tumorigenesis of breast cancer via inhibiting TLR4-mediated NF-KB signaling pathway. These findings also provided proof that inhibiting TLR4/NF-KB pathway by natural compounds was an effective chemopreventive strategy for breast cancer, and AT-I appeared to have potential value as a novel candidate for breast cancer treatment. 


\section{Abbreviations}

TLRs: Toll-liked receptors; NF-kB: Nuclear factor-kB; TMA: Tissue microarray; NMU: N-Nitroso-Nmethylurea; LPS: Lipopolysaccharide; PAMPs: pathogen-associated molecular patterns; EMT: Epithelial-

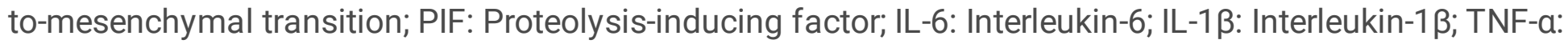
tumor necrosis factor-a

\section{Declarations}

\section{Conflict of interest}

The authors declare no conflict of interest.

\section{Availability of data and materials}

All the data are available within the article, or available from the corresponding author on reasonable request.

\section{Ethics approval and consent to participate}

This study was approved by the Ethics Committee of Sichuan Provincial Maternity and Child Health Care Hospital. The procedures in this study were approved by Laboratory Animal Care and Use Committees of the hospital.

\section{Consent for publication}

All authors agree to submit the article for publication.

\section{Competing interests}

The authors declare that they have no competing interests.

\section{Funding}

This work was mainly supported by the National Natural Science Foundation of China (81703922, 81803931), Basic Research Project of Health Commission of Sichuan Province (20PJ109), Basic Research Projects of Education Department of Sichuan Province (18ZB0164 and 18ZB0240) and Chengdu Key Research and Development Project (2019-YF05-01173-SN).

\section{Authors' contributions}

Fangyi Long and Ting Wang designed the studies, performed experiments and wrote the manuscript. Hong Lin, Xiqian Zhang and Jianhui Zhang helped with the experiments. Hongtao Xiao suggested experiments and revised the manuscript. All authors read and approved the final manuscript. 
None.

\section{References}

1. Siegel RL, Miller KD, Goding Sauer A, et al. Colorectal cancer statistics, 2020. CA Cancer J Clin. 2020;1(70):7-30.

2. Meric F, Buchholz TA, Mirza NQ, et al. Long-term complications associated with breast-conservation surgery and radiotherapy. Ann Surg Oncol. 2002;9(6):543-9.

3. Yang G, Nowsheen S, Aziz K, et al. Toxicity and adverse effects of Tamoxifen and other anti-estrogen drugs. Pharmacol Ther. 2013;139(3):392-404.

4. Kawai T, Akira S. The role of pattern-recognition receptors in innate immunity: update on Toll-like receptors. Nat Immunol. 2010;11(5):373-84.

5. O'Neill LA, Golenbock D, Bowie AG. The history of Toll-like receptors - redefining innate immunity. Nat Rev Immunol. 2013;13(6):453-60.

6. Sato-Kaneko F, Yao S, Ahmadi A, et al. Combination immunotherapy with TLR agonists and checkpoint inhibitors suppresses head and neck cancer. JCl insight. 2017;2(18):e93397.

7. Rodell CB, Ahmed MS, Garris CS, et al. Development of adamantane-conjugated TLR7/8 agonists for supramolecular delivery and cancer immunotherapy. Theranostics. 2019;9(26):8426.

8. Ray A, Tian Z, Das DS, et al. A novel TLR-9 agonist C792 inhibits plasmacytoid dendritic cell-induced myeloma cell growth and enhance cytotoxicity of bortezomib. Leukemia. 2014;28(8):1716-24.

9. Rajamanickam V, Yan T, Xu S, et al. Selective targeting of the TLR4 co-receptor, MD2, prevents colon cancer growth and lung metastasis. Int J Biol Sci. 2020;16(8):1288-302.

10. Urban-Wojciuk Z, Khan MM, Oyler BL, et al. The role of TLRs in anti-cancer immunity and tumor rejection. Front Immunol. 2019;10:2388.

11. Yang $H$, Zhou H, Feng $P$, et al. Reduced expression of Toll-like receptor 4 inhibits human breast cancer cells proliferation and inflammatory cytokines secretion. J Exp Clin Cancer Res. 2010;29:92.

12. Eskiler GG, Özkan AD, Kaleli S, et al. Inhibition of TLR4/TRIF/IRF3 signaling pathway by curcumin in breast cancer cells. J Pharm Pharm Sci. 2019;22:281-91.

13. Ruqiao L, Yueli C, Xuelan Z, et al. Rhizoma Atractylodis macrocephalae: a review of photochemistry, pharmacokinetics and pharmacology. Pharmazie. 2020;75(2):42-55.

14. Wu YX, Lu WW, Geng YC, et al. Antioxidant, antimicrobial and anti-inflammatory activities of essential oil derived from the wild rhizome of Atractylodes macrocephala Koidz. Chem Biodivers. 2020;17:e2000268.

15. Zhang JL, Huang WM, Zeng QY. Atractylenolide I protects mice from lipopolysaccharide-induced acute lung injury. Eur J Pharmacol. 2015;765:94-9. 
16. More S, Choi DK. Neuroprotective role of Atractylenolide-I in an in vitro and in vivo model of parkinson's disease. Nutrients. 2017;9(5):451.

17. Li Y, Wang Y, Liu Z, et al. Atractylenolide I Induces Apoptosis and Suppresses Glycolysis by Blocking the JAK2/STAT3 Signaling Pathway in Colorectal Cancer Cells. Front Pharmacol. 2020;11:273.

18. Guo W, Liu S, Ju X, et al. The antitumor effect of hinesol, extract from Atractylodes lancea (Thunb.) DC. by proliferation, inhibition, and apoptosis induction via MEK/ERK and NF-KB pathway in nonsmall cell lung cancer cell lines A549 and NCl-H1299. J Cell Biochem. 2019;120(11):18600-7.

19. Fu XQ, Chou JY, Li T, et al. The JAK2/STAT3 pathway is involved in the anti-melanoma effects of atractylenolide I. Exp Dermatol. 2018;27(2):201-4.

20. Liu H, Zhang G, Huang J, et al. Atractylenolide I modulates ovarian cancer cell-mediated immunosuppression by blocking MD-2/TLR4 complex-mediated MyD88/NF-kB signaling in vitro. J Transl Med. 2016;14(1):1-12.

21. Liu Y, Jia Z, Dong L, Wang R, Qiu G. A randomized pilot study of atractylenolide I on gastric cancer cachexia patients. Evid Based Complement Alternat Med. 2008;5(3):337-44.

22. Rojo F, González-Pérez A, Furriol J, et al. Non-canonical NF-kB pathway activation predicts outcome in borderline oestrogen receptor positive breast carcinoma. Br J Cancer. 2016;115(3):322-31.

23. Thompson HJ, McGinley JN, Rothhammer K, et al. Rapid induction of mammary intraductal proliferations, ductal carcinoma in situ and carcinomas by the injection of sexually immature female rats with 1-methyl-1-nitrosourea. Carcinogenesis. 1995;16(10):2407-11.

24. Wang $T$, Long $F$, Zhang $X$, et al. Chemopreventive effects of atractylenolide II on mammary tumorigenesis via activating Nrf2-ARE pathway. Oncotarget. 2017;8(44):77500-14.

25. Khademalhosseini M, Arababadi MK. Toll-like receptor 4 and breast cancer: an updated systematic review. Breast Cancer. 2019;26(3):265-71.

26. Zandi Z, Kashani B, Poursani EM, et al. TLR4 blockade using TAK-242 suppresses ovarian and breast cancer cells invasion through the inhibition of extracellular matrix degradation and epithelialmesenchymal transition. Eur J Pharmacol. 2019;853:256-63.

27. Li J, Yin J, Shen W, et al. TLR4 promotes breast cancer metastasis via Akt/GSK3 $\beta / \beta$-catenin pathway upon LPS stimulation. Anat Rec. 2017;300(7):1219-29.

28. Liao SJ, Zhou YH, Yuan Y, et al. Triggering of Toll-like receptor 4 on metastatic breast cancer cells promotes av $\beta 3$-mediated adhesion and invasive migration. Breast Cancer Res Treat. 2012;133(3):853-63.

29. Connelly L, Barham W, Onishko HM, et al. Inhibition of NF-kappa B activity in mammary epithelium increases tumor latency and decreases tumor burden. Oncogene. 2011;30(12):1402-12.

30. Płóciennikowska A, Hromada-Judycka A, Borzęcka K, et al. Co-operation of TLR4 and raft proteins in LPS-induced pro-inflammatory signaling. Cell Mol Life Sci. 2015;72(3):557-81.

31. Chen CY, Kao CL, Liu CM. The Cancer Prevention, Anti-Inflammatory and Anti-Oxidation of Bioactive Phytochemicals Targeting the TLR4 Signaling Pathway. Int J Mol Sci. 2018;19(9):2729. 
32. Wang W, Nag SA, Zhang R. Targeting the NFKB signaling pathways for breast cancer prevention and therapy. Curr Med Chem. 2015;22(2):264-89.

33. Shi H, Wang XL, Quan HF, et al. Effects of Betaine on LPS-Stimulated Activation of Microglial M1/M2 Phenotypes by Suppressing TLR4/NF-KB Pathways in N9 Cells. Molecules. 2019;24(2):367.

34. Chan MM, Lu X, Merchant FM, et al. Gene expression profiling of NMU-induced rat mammary tumors: cross species comparison with human breast cancer. Carcinogenesis. 2005;26(8):1343-53.

35. Chan MM, Lu X, Merchant FM, et al. Serial transplantation of NMU-induced rat mammary tumors: a model of human breast cancer progression. Int J Cancer. 2007;121(3):474-85.

\section{Figures}

(A)
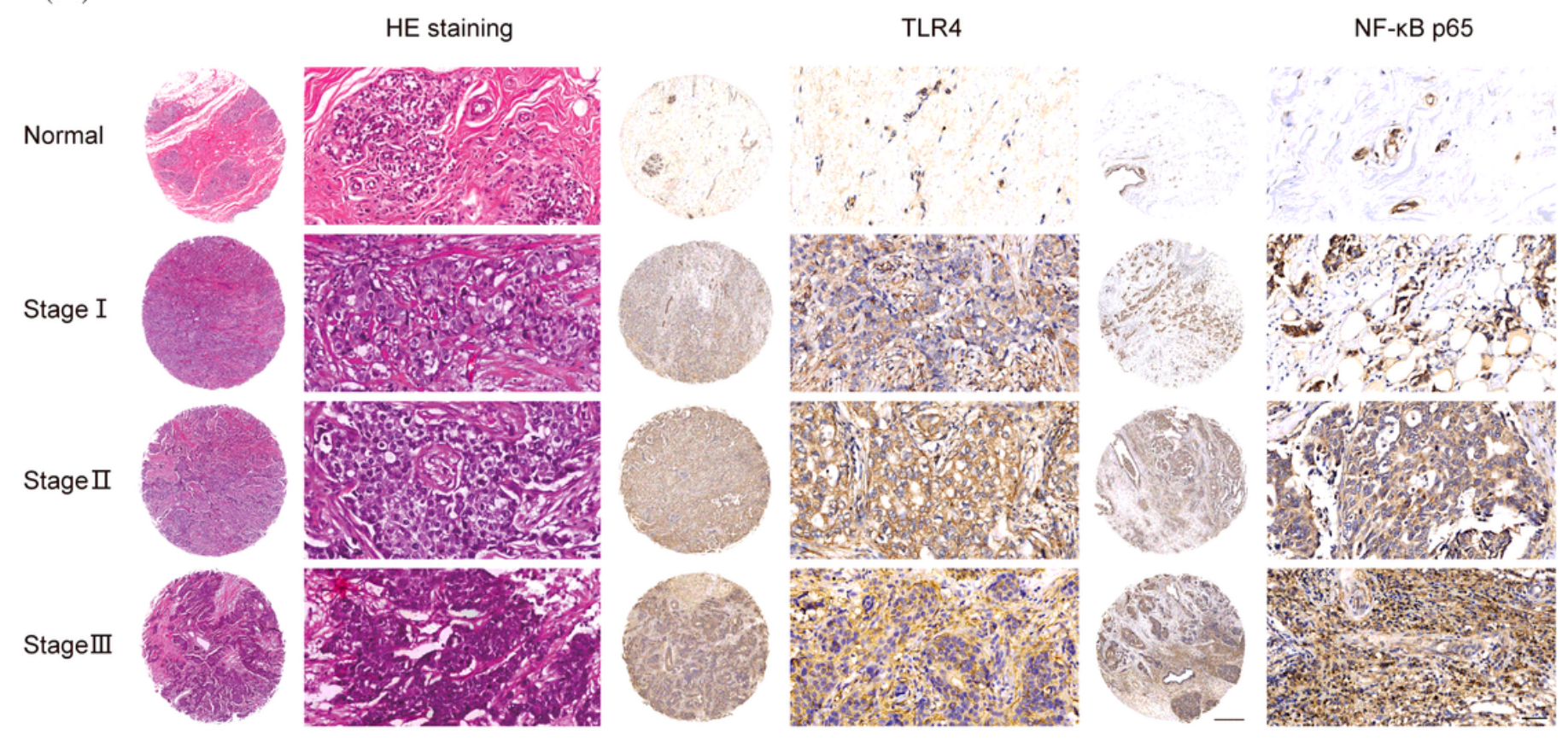

(B)

(C)

(D)
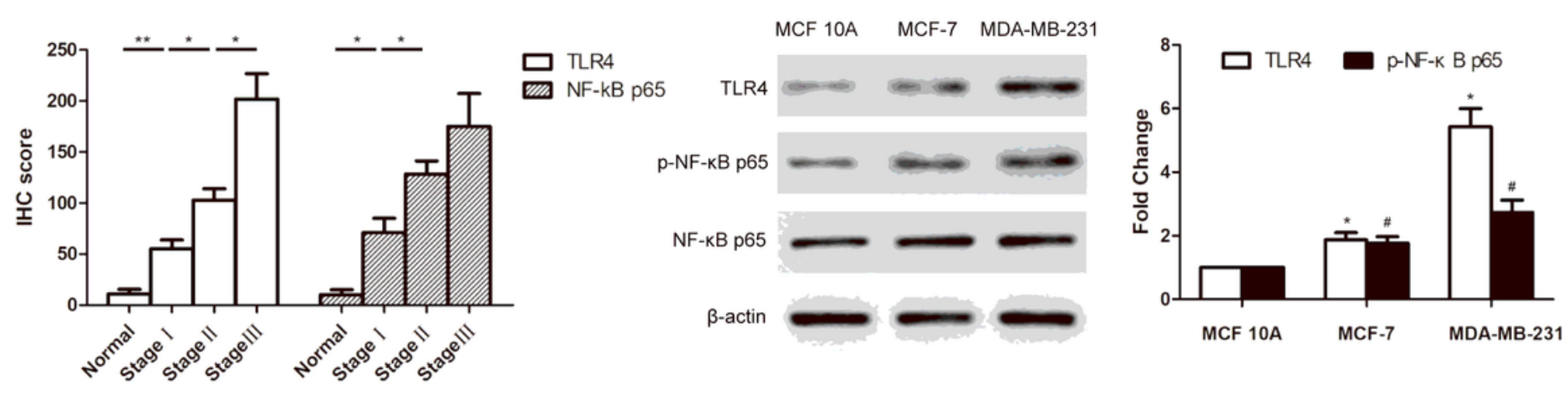

\section{Figure 1}

TLR4 and NF-KB were over expressed in breast cancer and correlated with TNM stages. $(a, b)$ Representative immunohistochemistry staining for TLR4 and NF-KB in normal breast tissues and breast 
cancer tissues with different TNM stages. ${ }^{*} \mathrm{P}<0.05,{ }^{*} \mathrm{P}<0.01$. (c, d) The expression of TLR4 and NF-KB in MCF 10A, MCF-7 and MDA-MB-231 cells by western blot $(n=3) .{ }^{*}<<0.05, \# P<0.05$, compared with MCF $10 \mathrm{~A}$ cells.

(A)
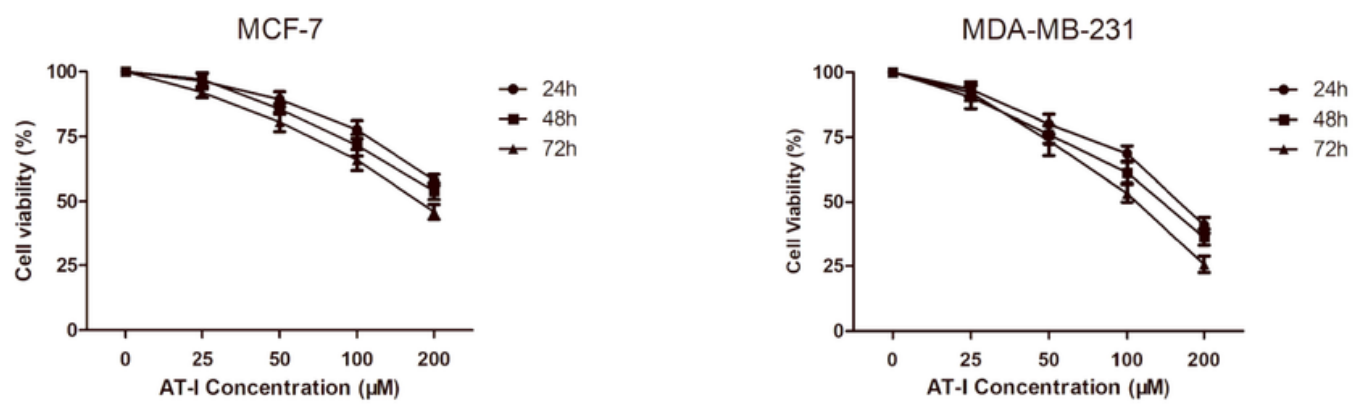

(B)
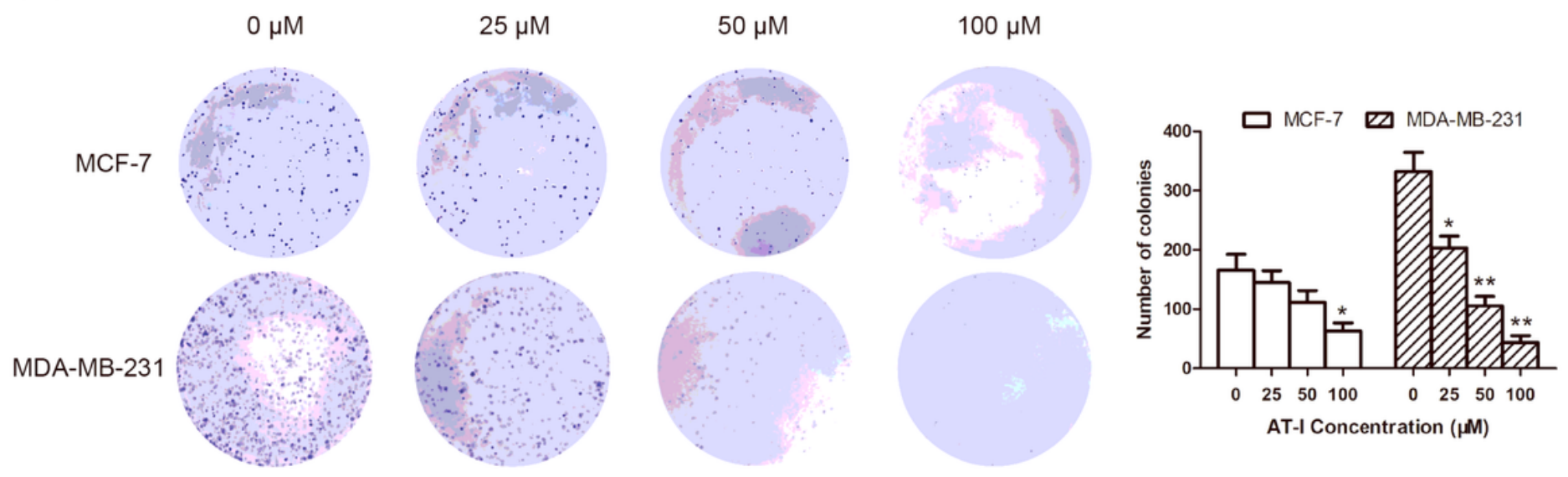

(C)
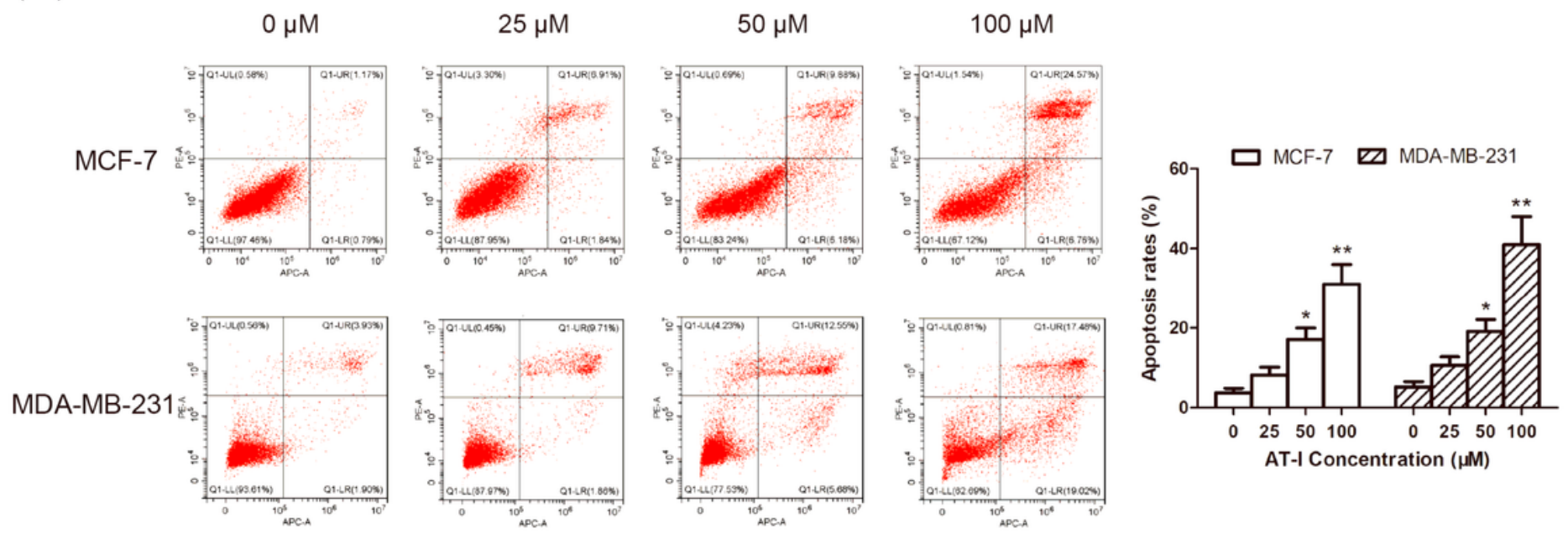

Figure 2

AT-I inhibited cell growth and induced apoptosis in breast cancer cells. (a) MCF-7 and MDA-MB-231 cells were treated with AT-I (0-200 $\mu \mathrm{M})$ for 24,48 and $72 \mathrm{~h}$ to determine cell viability $(\mathrm{n}=3)$. (b) MCF-7 and MDA-MB-231 cells were treated with AT-I (0-100 $\mu \mathrm{M})$ for $48 \mathrm{~h}$ and then applied for colony formation. The number of colonies was counted after 14 days $(n=3)$. ${ }^{*}<0.05, * * P<0.01$, compared with control. (c) 
MCF-7 and MDA-MB-231 cells apoptosis assay after treatment with AT-I $(0-100 \mu \mathrm{M})$ for $48 \mathrm{~h}(\mathrm{n}=3)$. ${ }^{*} \mathrm{P}<$ $0.05, * * \mathrm{P}<0.01$, compared with control.

(A)

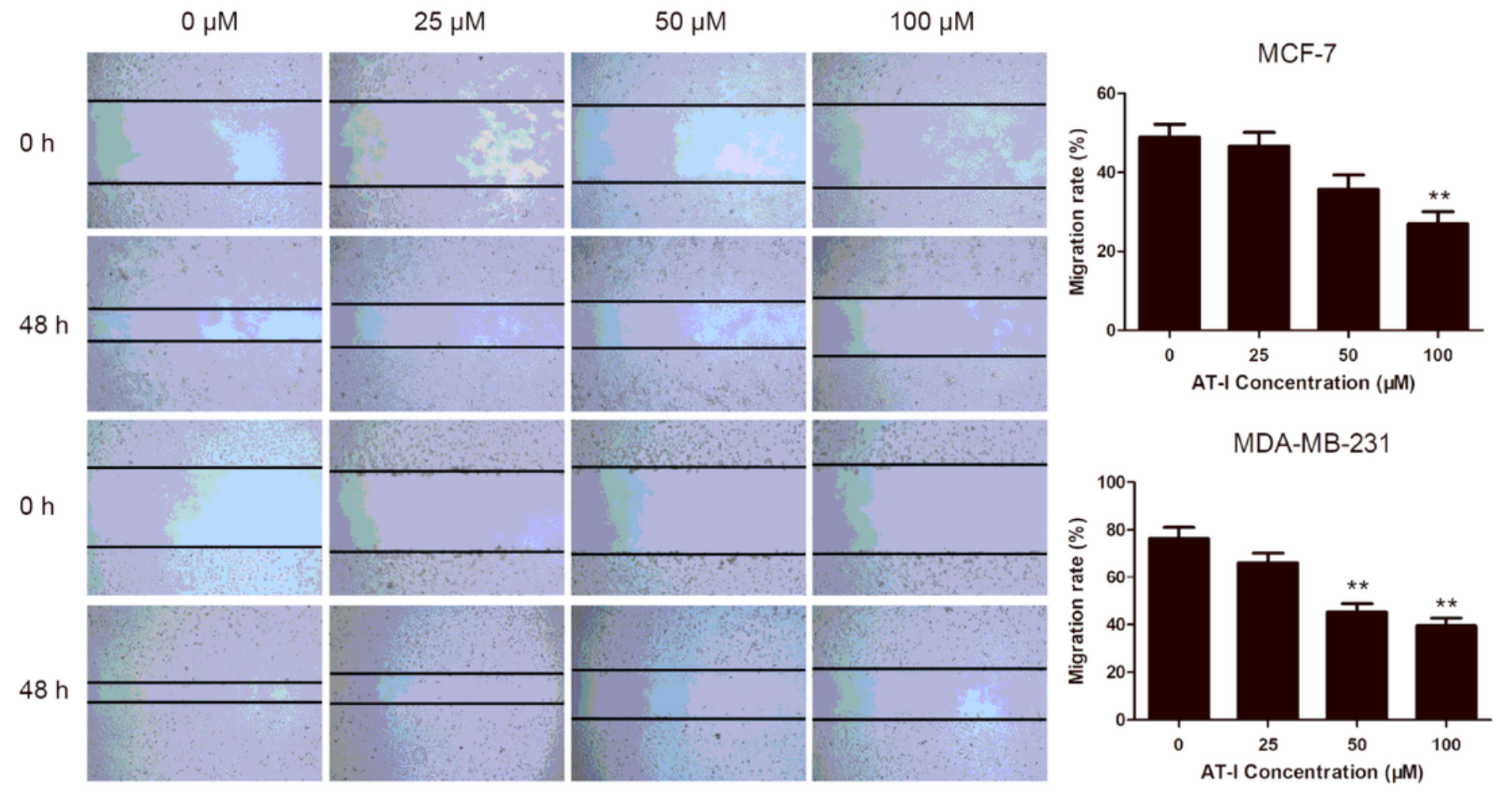

(B)
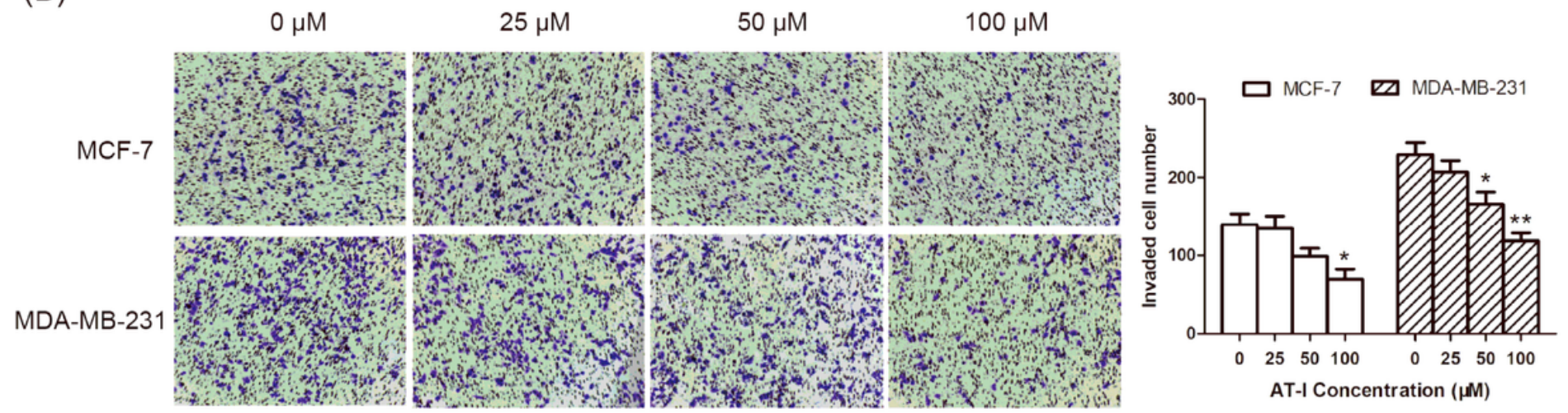

Figure 3

AT-I inhibited cell migration and invasion. (a) The migration capability of MCF-7 and MDA-MB-231 cells were calculated by wound healing assay after treatment with AT-I (0-100 $\mu \mathrm{M})$ for $48 \mathrm{~h}(40 \times$ magnification) $(n=3) .{ }^{*} P<0.01$, significantly different compared with the control. (b) Transwell invasion assay showed the number of invaded cells in MCF7 and MDA-MB-231 cells treated with different concentrations of AT-I $(0-100 \mu \mathrm{M})$ for $48 \mathrm{~h}\left(100 \times\right.$ magnification) $(\mathrm{n}=3)$. ${ }^{\star} \mathrm{P}<0.05,{ }^{*} \mathrm{P}<0.01$, compared with control. 
(A)

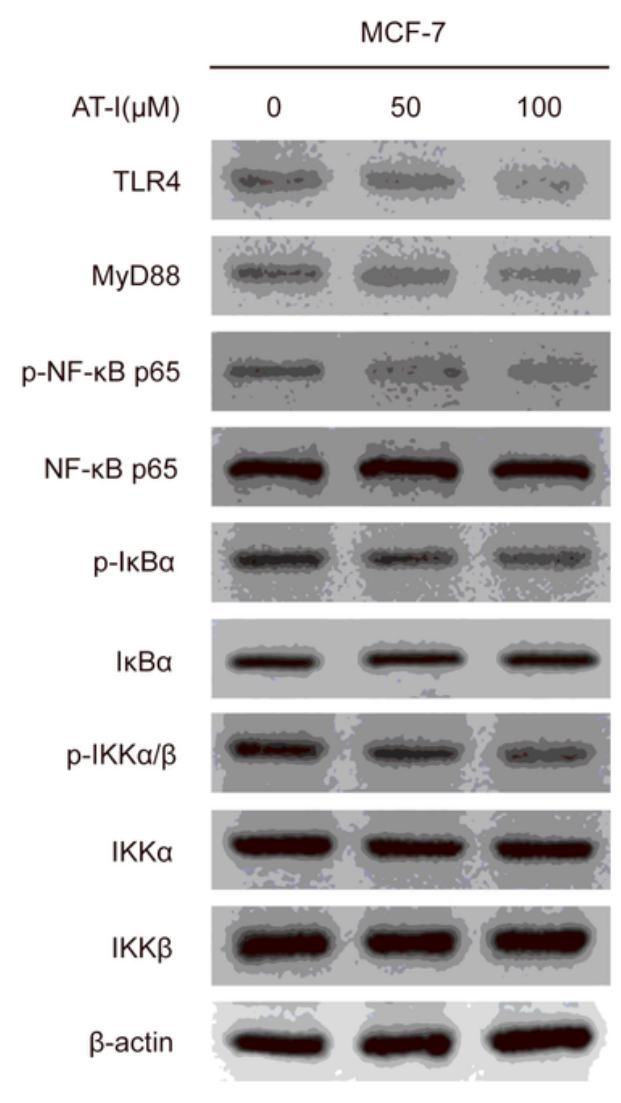

(C)

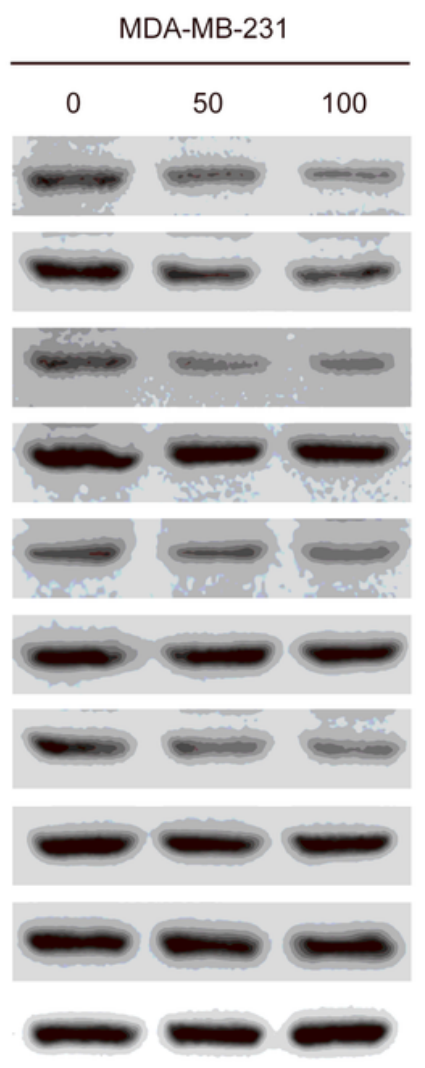

(D)

MCF-7

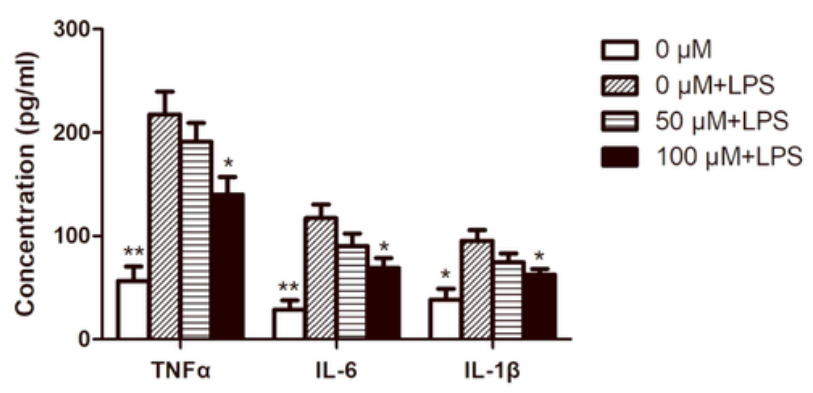

(B)

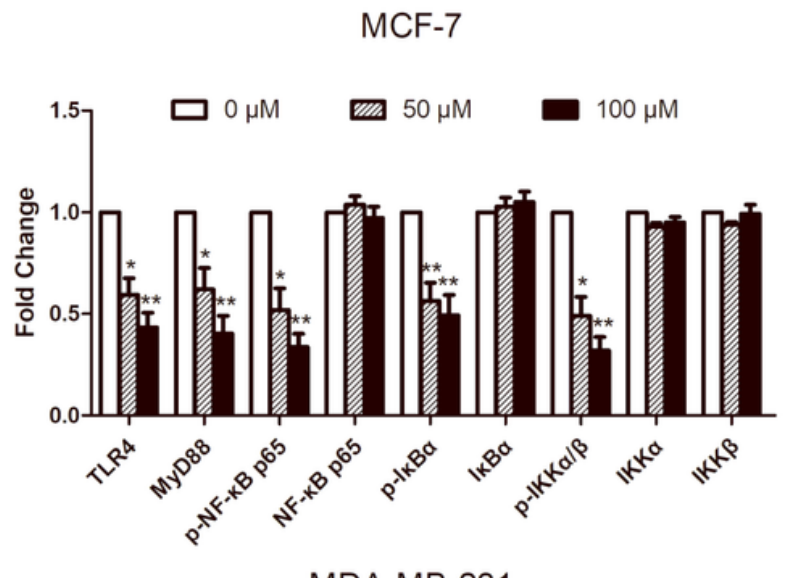

\section{MDA-MB-231}

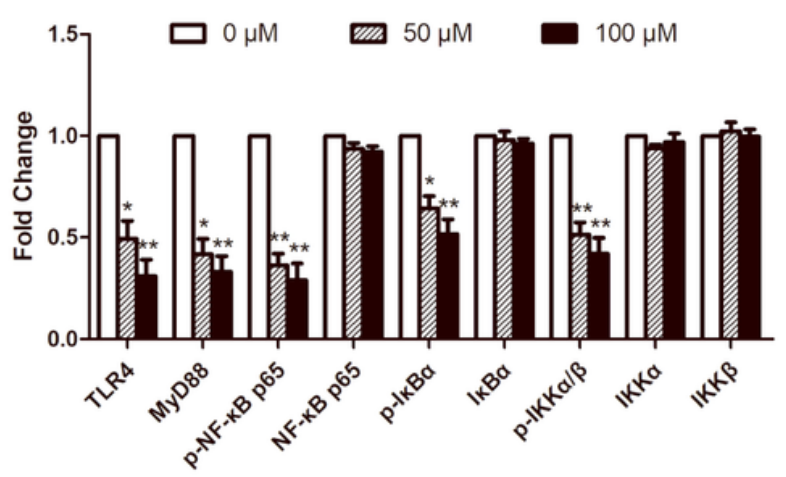

MDA-MB-231

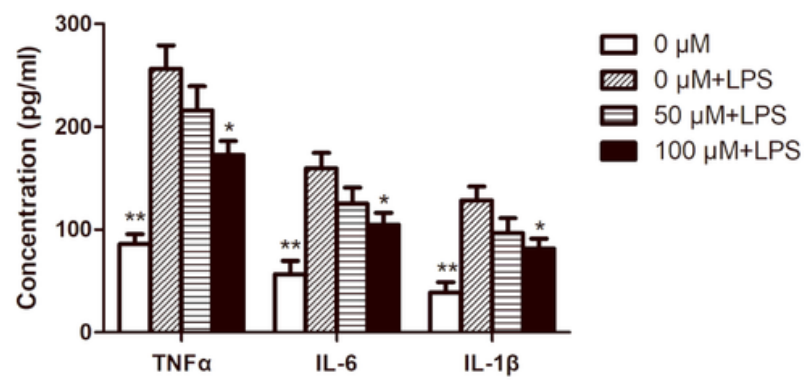

Figure 4

AT-I regulated TLR4/NF-KB signaling pathway in breast cancer cells. $(a, b)$ The effects of AT-I on TLR4/NF-KB signaling pathway were measured by western blot assay $(n=3) .{ }^{*} P<0.05,{ }^{\star} P<<0.01$, compared with control. (c, d) The levels of TNF-a, IL- 6 and IL-1 $\beta$ in the supernatants of cells were measured by ELISA assay $(n=3)$. ${ }^{\star} P<0.05$, ${ }^{\star *} P<0.01$, compared with the LPS treated control cells. 
(A)
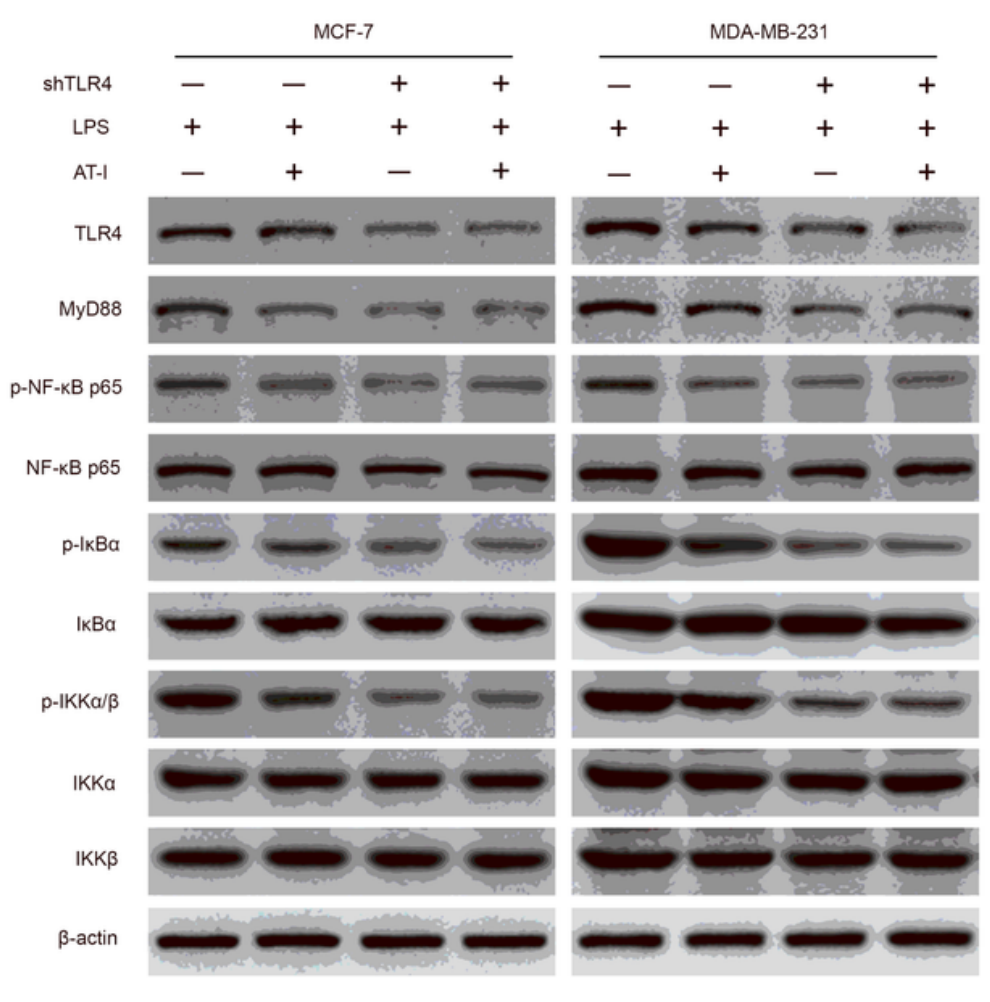

(C)

MCF-7

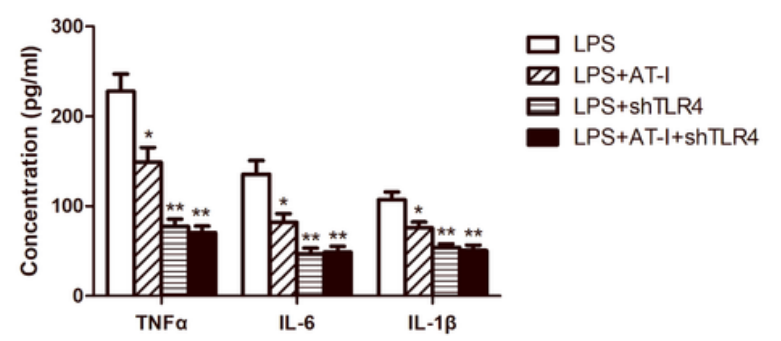

(B)
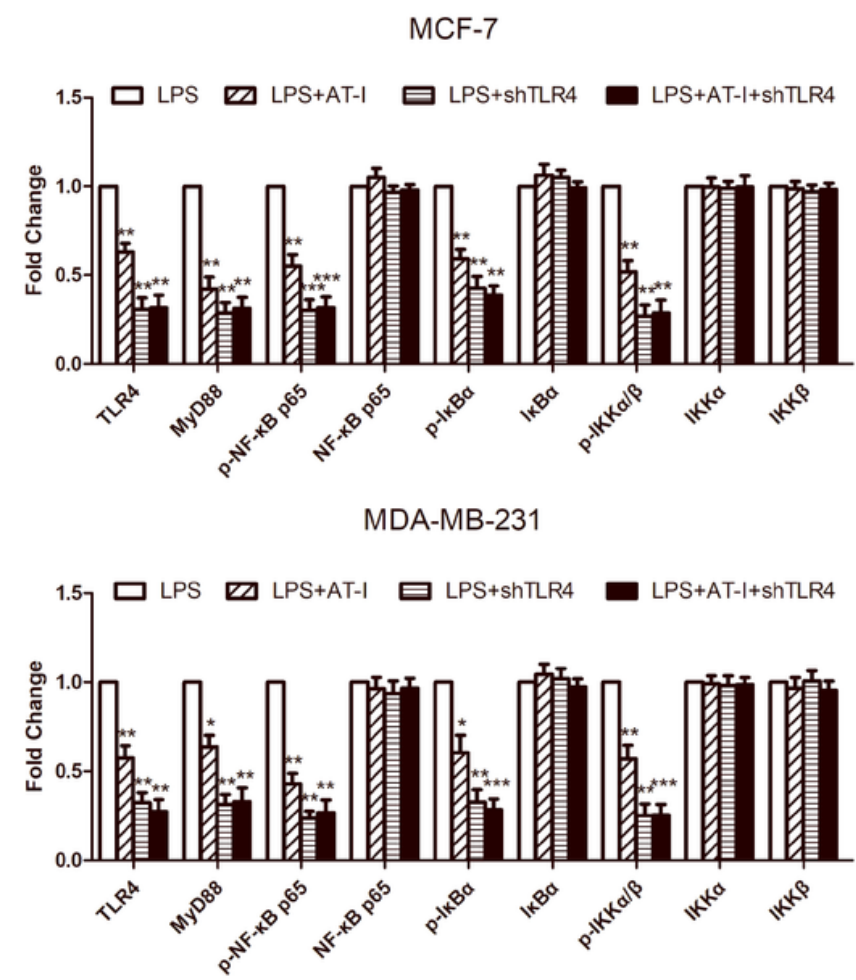

(D)

MDA-MB-231

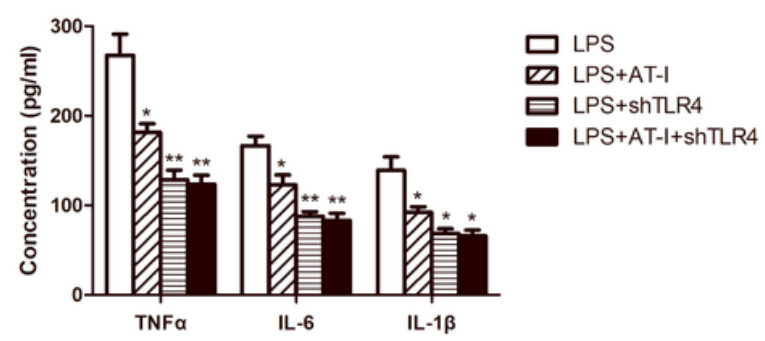

Figure 5

The effects of AT-I on suppressing tumorigenesis was mediated by TLR4. The shTLR4 plasmid was used to transfect breast cancer cells, and then western blot and ELISA assays were used to compare related proteins expression with untransfected cells after cells had been pre-treated in presence or absence AT-I for $48 \mathrm{~h}$ during LPS stimulation. $(\mathrm{a}, \mathrm{b})$ The expression of TLR4/NF-KB signaling pathway was detected by western blot assay $(n=3)$. ${ }^{*}<0.05,{ }^{*} P<0.01$, ${ }^{\star \star *} P<0.001$, compared with LPS treated cells. $(c, d)$ The levels of TNF- $\alpha$, IL- 6 and IL- $1 \beta$ in the cell supernatants were measured by ELISA assay $(n=3)$. ${ }^{*}<0.05$, $\star \star P<0.01$, compared with LPS treated cells. 
$(\mathrm{A})$

(B)

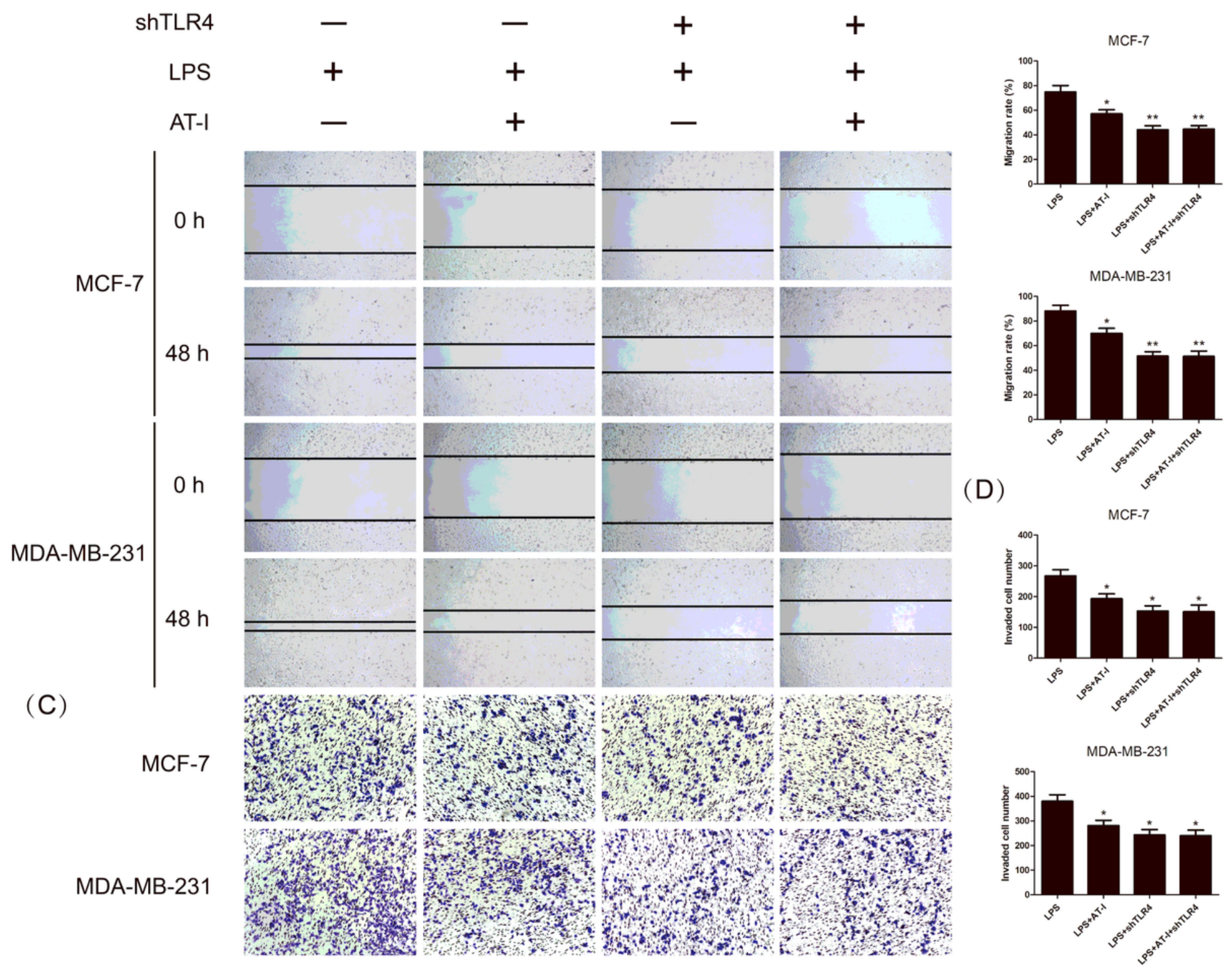

\section{Figure 6}

The effects of AT-I on cell migration and invasion was mediated by TLR4. LPS induced shTLR4 transfected and control cells were treated with AT-I, and then seeded in 24-well plates or transwell chamber coated with matrigel. $(a, b)$ The migration capability were calculated by wound healing assay (40×magnification) $(n=3) .{ }^{*} P<0.05,{ }^{*} P<0.01$, compared with the LPS treated cells. $(c, d)$ The invasion capability were calculated by transwell invasion assay (100xmagnification) $(n=3)$. ${ }^{*}<0.05$, compared with LPS treated cells. 
(A)

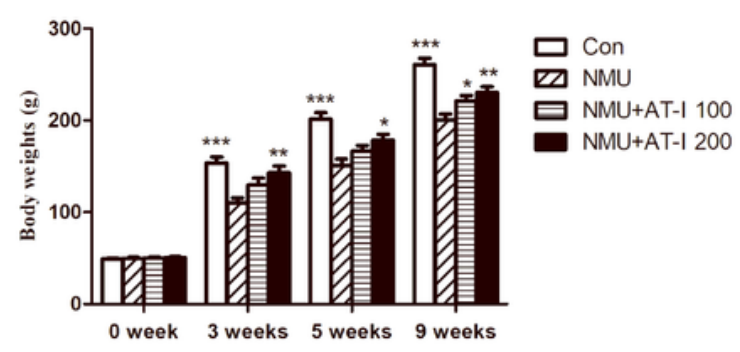

(C)

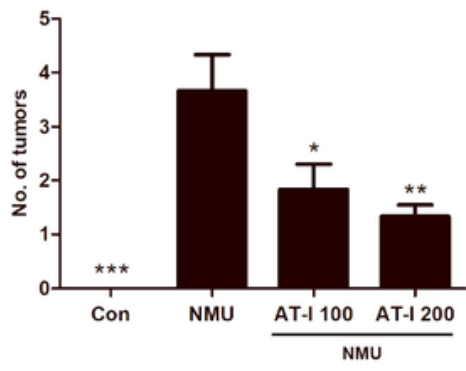

$(\mathrm{E})$

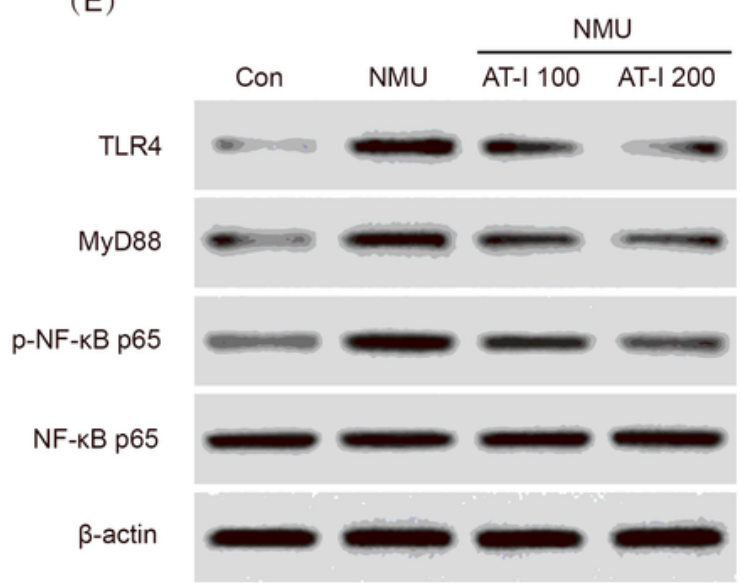

(B)

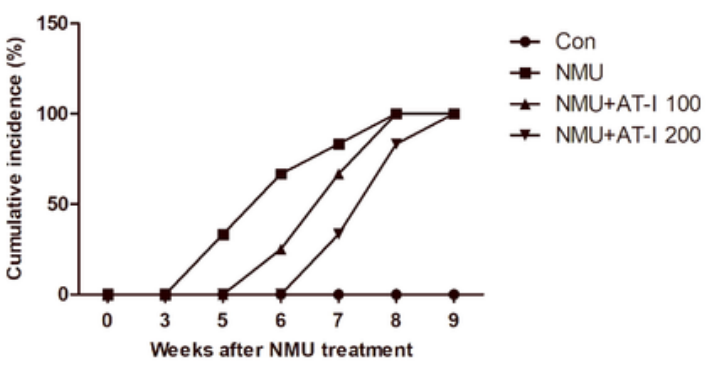

(D)

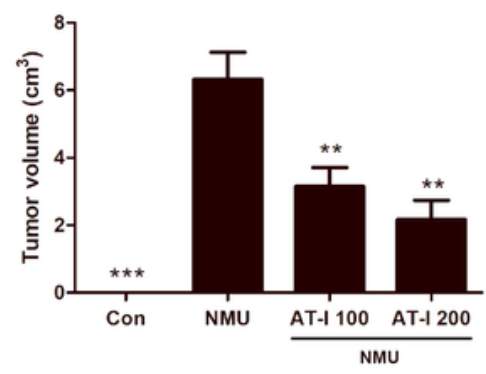

$(\mathrm{F})$

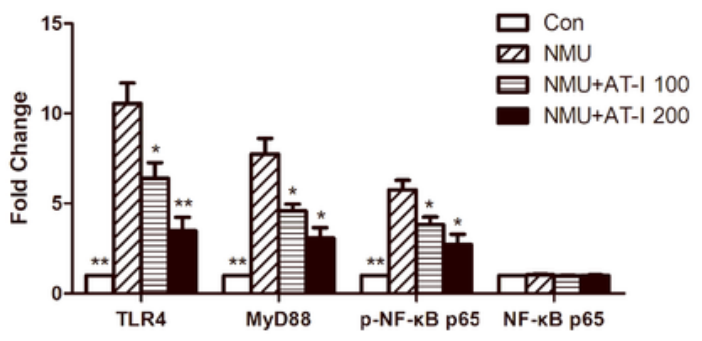

(G)

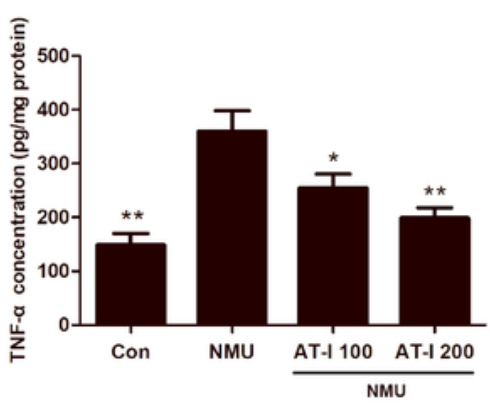

(H)
(I)
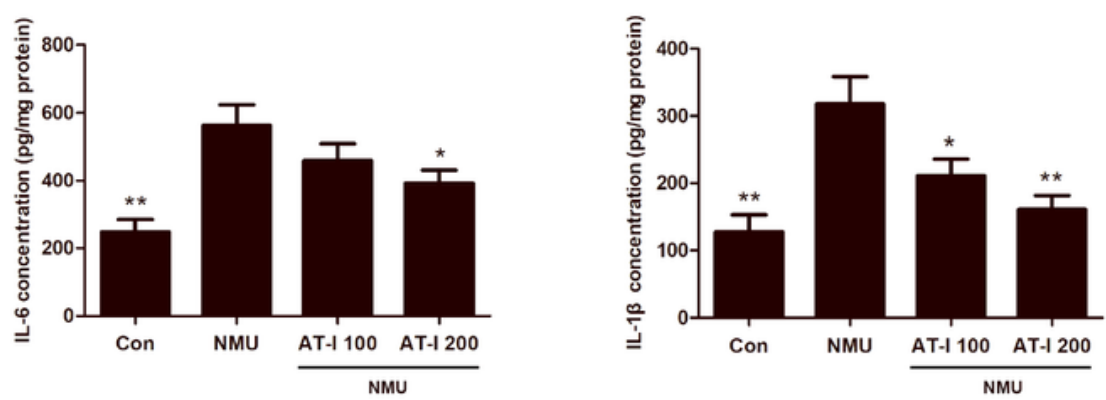

\section{Figure 7}

AT-I inhibited NMU-induced rat breast cancer. The NMU-induced rats were treated with control or AT-I for 9 weeks $(n=6)$. (a) Body weights of rats in all groups at 0,3, 5 and 9 weeks. (b) Palpable tumor incidence was recorded every week. (c) Average tumor number at 9 week. (d) Average tumor volume at 9 week. (e, f) Rat breast tissues were kept to detect TLR4/NF-KB pathway by western blot assay at the end of 
experiment. (g-i) TNF-a, IL- 6 and IL-1 $1 \beta$ levels in rat breast tissues were analyzed by ELISA at the end of experiment. ${ }^{*} P<0.05,{ }^{*} \mathrm{P}<0.01,{ }^{* \star *} \mathrm{P}<0.001$, compared with NMU group. 